\title{
Coercion and the labour contract - revisiting Glasbrook Brothers and the political fiction of Lewis Jones
}

\author{
Melanie L. Williams \\ University of Exeter
}

\begin{abstract}
In his tale of the struggles and privations of the mining community in the industrial south of Wales in the early decades of the $20^{\text {th }}$ century, Lewis Jones, ex-miner and socialist activist, put aside the usual tools of political activism - of oratory and pamphlet propaganda - and instead turned to fiction as a means of educating and mobilising the political energy of the workforce.. In doing so, Jones represented the extent to which the law was pivotal to the social organisation delivering injustice to working people. When one turns to history and to the legal record, the contestable accounts, elisions and absences from the record speak eloquently of the extent to which selective doctrine contribute to that injustice. The resultant message resonates with debates on the relationship between society, politics and the rule of law itself.
\end{abstract}

\section{INTRODUCTION: LAW, LITERATURE AND HISTORIOGRAPHY}

With interdisciplinary study has come increasing recognition that concerns as to the contestability of accounts and truths may reveal the influence of narrative, as well as institutional, power. Not only is there recognition that assertions of truth are most easily made by those with the power to harness authoritative media ${ }^{1}$ - and in this may be included the law as well as the press; increasingly scholarly attention has also turned to the role played by the power of narrative in such assertions. In the interdisciplinary body of scholarship that has come to be known as 'law and literature' in particular it is argued that, as a human activity steeped in the dilemmas of the moment, the world of literature may often provide insights otherwise lost to the formal record ${ }^{2}$. In

\footnotetext{
${ }^{1}$ A long-standing realisation, as satirised by George Orwell and his Ministry of Truth in the novel Nineteen Eighty Four, but more recently the concept of the alternative and notionally predominant 'truth' has been admitted into jurisprudential process for example in the Truth and Reconciliation hearings of South Africa. ${ }^{2}$ Several texts may be cited in this regard, but see for example works on law and literature by Maria Aristodemou, James Boyd White, Adam Gearey, Brook Thomas, Ian Ward, Melanie Williams.
} 
addition it may be argued that narrative processes are so intrinsic to every account as to provide reason to query the status formerly accorded to 'factual' as opposed to 'fictional' sources, given that all will carry contestable elements ${ }^{3}$.

Though lawyers refer to a linear legal 'history' as the touchstone of authoritative knowledge concerning the foundations and development of the law, it is increasingly apparent that historiography - history with a consciousness of multiple influences, of interpretative practice, contestable truths and narrative strands - is an enriching additional approach to understanding past and present questions. A historiography of law undertaken from a vantage point sufficiently distant to provide a truly dispassionate account of the role and impact of the law in the daily lives of its citizens has yet to be written. Not only the separation of politics from law, but also the streamlining of doctrinal authority and the separation of allegedly independent cognate strands into legal specialisms, have all contributed to the artefacts of law.

In the present essay, questioning the relationship between historiography and the law that relating to the labour contract in particular - was prompted by a potent work of fiction Cwmardy and We Live ${ }^{4}$ by Lewis Jones. The power of the work comes in part from its urgent yet simple depiction of the politicisation of a community, a community based upon the real industrial communities of South Wales. In terms of its power to contest the 'truths' of more authoritative canons, the text is perhaps less radical than some in that it bears some relation to factual events and personalities, being in part a dramatisation of a real community and its history. Doubtless the sequence and magnitude of events as represented to some extent serves political as well as dramatic imperatives in the text and for this reason cannot be relied upon as a document of absolute evidential integrity. Nevertheless the central issues of exploitative practices, compliant jurisprudence and a vulnerable labour force reflect genuine aspects of the historical and legal moment, a moment itself poorly and partially represented by the conventional historical gloss. In particular the dramatisation highlights a polarisation, where a divisive and questionable fabric of public and private law interaction alienates a citizenry of drive and integrity.

\footnotetext{
${ }^{3}$ The authors cited at fn 2, above, all deal with this issue in various ways, but in broader philosophical terms, so too does Stanley Fish (1989) for example.

${ }^{4}$ Lewis Jones, (Jones, 2006) Cwmardy, We Live, was first published in1937. Actually a 'pair' of novels, now published together as one narrative, the first section Cwmardy, relates the 'story' of the mining community, their relationships and struggles, whilst We Live, a continuation of this story, concentrates more fully upon consolidating a vision of political activism, culminating in support for the freedoms threatened in the Spanish Civil War.
} 
Anyone familiar with South Wales will know that it has a remarkable social and industrial history. A tradition of oratory and fierce debate combined with a precocious and exacting industrial revolution has produced some fiery challenges in politics and law. ${ }^{5}$ In Wales in particular, the struggle was impassioned and informed because of the working class commitment to faith, to community and to education (the working communities of Wales each contributed their tiny savings to the establishment of the University of Wales in the later $19^{\text {th }}$ century; whilst the Miner's Library in Swansea holds a remarkable collection of philosophical and political literature, again bought with the contributions of the miners themselves). This commitment was enduring because of the intimate link between the issues and the very terms of existence, that is, the preservation of a bare living wage in return for labour conditions of danger and uncertainty.

It would appear that the work of Lewis Jones came into being precisely because of a conviction that the offices of oratory, politics or law were not sufficiently responsive to meet the challenge of human need. In dramatising events in the industrial south of Wales in the early decades of the $20^{\text {th }}$ century, Jones put aside the usual tools of political activism of oratory and propaganda - and instead set out to educate and mobilise the political energy in the workforce through the combination of narrative and dramatisation of key events and ideas. Though guided by a fellow activist towards this narrative turn, Jones was clearly receptive to the development. Against a background of constant suffering in the working community - a community hopeful of empowerment and equity through the ballot box, Jones had witnessed the failure of this promise of equity: a failure of meaningful representation in local and national politics, the dilution and exhaustion of union activism, the criminalisation of key representatives (including Jones himself), biased reporting by the media and prejudicial treatment by the law. This essay therefore examines the convergence of historiographic, legal and cultural processes represented in the recourse to narrative. It does not set out to provide an exhaustive critique of industrial relations law or of the origin and use of force by state agents per se, but rather looks at the core ideas giving rise to such

\footnotetext{
${ }^{5}$ Wales, the site of the Rebecca riots of 1843 , as well as being a pivotal player in the Chartist movement of 1848 , has produced prominent political figures, including David Lloyd George and Aneurin Bevan. Stimulated by harsh social conditions, political activism and socialist sympathies have played a natural and pivotal role in Welsh cultural as well as political life and the reputation of the working people of Wales in this regard is widely known. In the early part of the $20^{\text {th }}$ century, links stretched from Wales to Russian Trade Unionism and the International Communist movement. From America, Paul Robeson, singer, actor and civil rights activist, visited South Wales many times between 1929 and 1939. In 1938, Robeson sang to the 7000 people who attended the Welsh International Brigades Memorial in Mountain Ash to commemorate the 33 Welshmen who had died in Spain. He told the audience 'I am here because I know that these fellows fought not only for me but for the whole world. I feel it is my duty to be here'. (See page dedicated to Paul Robeson on the Coalfield Web Materials site at www.agor.org.uk).
} 
difficulties - of the nexus between labour, contract and coercion on the one hand, and political, legal and historical narrative on the other.

Lewis Jones has received very little recognition in literary terms - his workaday characters and settings do not attempt a profoundly literary approach, nor is the text imbricated with overtly philosophical or meta-theoretical perspectives. Though one can readily identify the work as 'political' literature, it does not sit easily within the genre, being neither political satire nor intrigue. The text receives minimal notice - barely a paragraph - in texts dedicated to British political fiction. Harvie (1991: p. 182) briefly observes that

'Revolutionary' literature...diminished the sense of historical change in class and economic relationships, and the religious-radical tradition of millenial protest. Perhaps we see this best in the 'working-class novel'. Lewis Jones's Cwmardy (1937) and its sequel We Live (1939) take a Welsh mining valley from the 1900s to the Spanish Civil War. Jones's own Mardy, in Rhonnda, was one of the 'Little Moscow' fortresses of the Communist Party, but Jones presents Cwmardy as typical: communism and autodidact materialism take a back seat to Gemeinschaft...

whilst Raymond Williams (1982. p. 133-4) notes

...Cwmardy, the plot of which spans a whole lifetime, reveals a new class consciousness manifest in the cohesion of a mining town, which transforms the very nature of the struggle. In a brief early review, W.H. Williams pointed out that the evolution of class consciousness - something 'lacking in D.H. Lawrence' - added a new note to the novel. What Williams detected in Cwmardy was obviously the power of a new sensibility reaching forward into the future. The novel shows the inadequacy of mine management and opens up the possibility of control by the miners themselves.

Neither comment reflects the power of Jones's message - the kind of elegiac truth which filters through regarding the utter failure of politics and law. For both these commentators, whilst the themes sit pleasingly with certain political motivations, there is little to say about the stylistic qualities of the text - Jones is not consciously a modernist, a satirist, a lyricist. Arguably, this is absolutely deliberate, rather than merely a reflection of literary limitations - such stylistic interjections might well have interfered with the receptivity of the audience, a straitened community audience, to the message. Jones does however draw upon certain elements of modernist writing to empower the message of revolutionary politics, most notably in the realism with which he represents the brutal physical manifestations of 
prevailing cultural and political cruelties - the violent and needless industrial deaths, the brute reality of death itself, unmitigated (even for a young girl, Jane and her newborn child) by the religious nostrums which hitherto had solaced the workers:

The men worked in the most intolerable conditions. Excessive heat and the foetid atmosphere melted their flesh and left them like empty sacks at the end of their short shifts. The bodies they discovered each day were simply ghastly lumps of greasy putrefaction. Very few could be identified. In a short time it became known to the people of the valley that the explosion had left no survivors[...](Jones, p. 81).

This was to be the last occasion before they screwed the coffin down ready for the funeral next day...Len looked down and a look of horror filled his eyes. Jane's beautiful face was gone. In its place was a dirty yellow mask with snarling lips that curled back from shiny white teeth. A blackened penny grinned at him mockingly from each of her eyes. The roses had died and were now withered blotches on the white lace of her shroud. Dark blobs filled the places where her cheeks had been. The tiny shrunken form at her side was covered. A fusty smell rose from the coffin and reminded Len of the odour in his bed the night after Jane had died. (Jones, p. 112)

Action, rather than a fatalistic piety, will allow the people to overcome the injustices in life and in unnecessary deaths - this realism is key in giving force to the political message - 'the new sensibility reaching into the future' (as Raymond Williams expresses it, above). Such realism is also central to the carefully conveyed, micro-managed account of the network of corruptions and failings in the political system, from local council to state government, giving reason to the political message - that the people must take a stand. More prominent, literary, political writers, such as George Orwell, arguably fail on this front - the satirical fable of Animal Farm proving too allegorical, the deadly pessimism of Nineteen-Eighty Four too destructive. Jones is singular in combining the dramatisation as educative tool (conveying the vital links between the concepts of labour, power, politics and collective action, with the fabric of systems, of councils, federations, unions, laws, States, on a different register to the admittedly magnetic writings of Marx and Engels) with the signal to future political transformation. Indeed, elsewhere Raymond Williams lambasts the writings of Orwell - in Williams view, Orwell suffers from "the paradox of the exile", and Orwell's alienation, his inauthentic membership of the working community, contributes to 
the failure of his political message ${ }^{6}$. In contrast, one might believe that Jones would have fulfilled the aesthetic and political aspirations of Trotsky, whose expectations of a new 'revolutionary and socialist art' in Russia were largely disappointed. In Literature and Revolution, Trotsky decries the fact that post-revolutionary writers are failing the reasonable expectation of a literature of revolution. Returning instead to a misplaced romanticism, of the 'old' country and of the peasant, post-revolutionary Russian writers decry the very existence of 'proletarian' poetry and of industrial landscapes and workers, and thereby fail to deliver the long-awaited transformative message ${ }^{7}$ :

...Of "industrial rhythms," of proletarian poetry, of the very principle of it, Kliuev speaks with the natural contempt that comes to the lips of every "strong" peasant when he glances at the propagandist of socialism, the houseless city worker... When one speaks of revolutionary art, two kinds of artistic phenomena are meant: the works whose themes reflect the Revolution, and the works that are not connected with the Revolution in theme, but are thoroughly imbued with it...

Although Jones more closely fulfils this kind of artistic hope, creating seamless links between the values and identities of people and the broad ideological context, his revision of history - what might be called his historiographic position, and adherence to a simple, workaday prose, are practical, rather than aesthetic or ideological moves. Thus he demonstrates an interesting, 'pre-genre' example of what has come to be known, in the modern terminology, as 'historiographic metafiction'. Such texts have an association with 'postmodernist' literary and artistic development, in their playful engagement with history and with the notion of truth. Jones could not (and perhaps would not wish to) be counted as a legitimate member of this movement. His purpose is far from playful and indeed his practical engagement with the 'facts' of history, though to some extent politically aware, aesthetically it would appear, is quite unconscious. Yet the deliberate moves of historiographic metafiction - especially given a frequently political motivation - resonate quite closely with the less conscious co-ordinations of Jones. In her definition of 'historiographic metafiction', Hutcheon (1998:5) for example places emphasis upon the self-awareness of history and fiction as human constructs. Though the work of Jones cannot be described as 'self-reflexive', his awareness of history and fiction as human constructs is clear. His awareness of history as an artefact is surely informed by brutal

\footnotetext{
${ }^{6}$ For further discussion of Raymond Williams on Orwell, see Paul Thomas (1985).

${ }^{7}$ Leon Trotsky (2005), first published in 1924
} 
personal experiences as well as by his political education, whilst his use of fiction as tool as well as canvas suggests a freedom from the seductive powers of art. ${ }^{8}$

The patent injustice suffered by his beloved community was the driving force for Lewis Jones in his journey from oratory to fiction. Already engaged by political ideas as a result of the hardships of their working environment the working communities of South Wales had experienced limited success in pressing their claims for fairer wages and conditions. Much of Jones's text dramatises a struggle that is pivotal in Welsh industrial history, the story of Tonypandy in 1910-1911. As Smith (1999, pp.102-3) recounts, this was a time when

Rhondda labour leaders who variously combined a fervour for 'syndicalism' (workers' control to be achieved through the direct action of democratically organised unions) with the politics of the ballot box...then add the assembled forces of imported police and over twelve thousand colliers and their families out on strike until starved back after almost a year's embattled struggle.

Smith adds "No wonder John Morgan set out to write a libretto for his opera Mabon based on Tonypandy' and quotes the stimulus for Morgan, for whom

The scale of that drama in 1910-11...was epic.....Nowhere else in Europe was there such a startling revelation of the new political order of the century. Therefore to convey this scale the opera will need as large a chorus as is feasible. It cannot be a chamber work...

The origins of the dispute lay with increasingly harsh working conditions. As the mines were worked more intensively, extracting profitable coal became more dangerous and technically challenging. With the men obliged to extract a proportion of useless stone along with the coal, management forced the men to bear the impact of the losses, leading to an industrial dispute deriving from the men's plea that, already on minimal wages, they would be at the lowest subsistence point if management did not make some allowance for the unproductive element of the work. With an unrelenting management and already ravaged by a series of appalling industrial accidents, the men went on strike. The management attempted to circumvent the strikers by drafting in blackleg labour and

\footnotetext{
${ }^{8}$ The discussion in Hutcheon points up links between postmodernism, historiographic metafiction and the $20^{\text {th }}$ century political mind, links intimated in early form by Trotsky, at least in relation to the location of art. Hutcheon: 'It is no longer big news that the master narratives of bourgeois liberalism are under attack... whatever narratives or systems that once allowed us to think we could unproblematically and universally define public agreement have now been questioned by the acknowledgement of differences - in theory and in artistic practice' (Hutcheon,p. 6-7).
} 
colliery officials to keep the mines in working order and this led to unrest and the drafting in of police. Confrontations, exacerbated by a relatively small group of agitators attacking property, led to criminal charges being made against certain strikers and allowed the strikers to be characterised, not as the victims of a harsh and unjust industrial regime, but as an unruly mob, acting against the interests of the entire country. Though some advances were made on behalf of the workers in the ensuing years, the scale of those advances was small and the political efficacy of collective activity undercut by broader political intrigues. ${ }^{9}$ For some, such as Lewis Jones, the democratic process had proved itself to be of doubtful utility even when political representation was within sight. Global politics acquired an intimate relevance as fascism stalked with the Spanish civil war, and revolutionary politicisation of the workforce seemed the only way forward. Orthodox methods of political education and mobilisation - through lectures and pamphleteering were proving somewhat slow. The turn to fiction was a concerted educative tool in the attempt to mobilise the revolutionary political message.

In his tale of the travails of a mining community and the crises and tragedies pursuant upon the industry, Jones represents certain encounters with the law and notions of justice. These provide a plausible account of the encounters with the law in the 'real' as lived by the workers of the time and they bear some examination, illuminating the use of narrative in this regard. Though many issues of legal note arise in the text, three engagements with direct mechanisms of law are directly recorded: an Inquest, a deployment of police and army forces and a criminal prosecution. These events reflect some simple but fundamental criticisms of law. Of these events, it is however the second, the deployment of force - that of police force in particular - which is most clearly indicated by Jones as a source of concern. With the potential to be easily 'naturalised' as an everyday part of domestic order, this issue forms the key focus of the present essay.

\footnotetext{
${ }^{9}$ In the Trades Disputes Act (1906) trade unions were provided with notional immunity from liability for damages arising from strike actions. The statute was a belated political response to a series of controversial and adverse court decisions affecting the capacity of trade unions to strike, culminating in the Taff Vale judgement of 1901, which had rendered union funds, as funds of legal corporations, subject to economic liability for losses incurred by others as a result of union action. The Royal Commission on Safety resulted in the Mines regulation Act of 1911, still a cornerstone of protective legislation for underground workers; nevertheless, health and safety legislation did little to prevent the continuing occurrence of major disasters. The Minimum Wage Act of 1912 remained on the statute books until 1947, but its ameliorating intent was diluted in the final form. At the beginning of the $20^{\text {th }}$ century, the minimum age of entry into the coal industry was raised to thirteen years. In 1906, the mineworkers union participated for the first time in a Royal Commission on safety in the mines. Incessant campaigning alongside industrial action brought about the 1908 Eight Hours Act for mineworkers underground. As already indicated, in spite of the increasing health and safety legislation, however, the death toll in the industry remained high.
} 


\section{THE DEPLOYMENT OF FORCE AGAINST STRIKERS}

The deployment of the police and army as a containment measure in the management of an industrial strike provides a potentially instructive and significant illustration of the engagement between the people and the law. Such encounters are easily represented in the media and in history as a necessary move in the face of imminent chaos. At the height of the Tonypandy troubles, both police and troops were mobilised and this was indeed characterised in the press as a necessary response to violent disorder, though the local account recalls an entirely different interpretation, of decent and desperate people needlessly dishonoured and brutalised by such intervention, an intervention apparently supported by the Government in distant London. In Cwmardy, Jones represents all this, the strife, the attempt to exert state force through the police and the army, the indignant people and the resultant media version of events. Nevertheless, as far as the deployment of force is concerned, Jones directs most narrative suspicion and incredulity at the question of the legality of police deployment in particular, perhaps recognising that, whilst army forces may be easily and somewhat impenetrably submitted as a crucial resource for states in extremis - the use of the police is a different matter. Already a routine part of the domestic 'furniture', their use can all too readily be normalised as a neutral instrument of domestic order whilst serving the interests of the powerful.

Through the narrative of the development of industrial dispute, the reader gains insight through the eyes of the main protagonist, Len, son of experienced miner Big Jim. Len moves from fledgling miner, keen to learn the finer points of the craft, to politically aware representative of his peers as, time and again, he witnesses injustices wrought upon his fellow workmen. The inducement to strike is provided when the colliery company declares that it will no longer pay for the 'small coal' mined by the men, but only 'large coal'. ${ }^{10}$ The men calculate that on average small coal accounts for around $40 \%$ of each tram filled. Already working to capacity on bare subsistence wages, and constrained by the technical difficulty of extracting 'large coal', the edict portends ruin for the men. As Dai Cannon, miner and preacher expresses it:

Mr Chairman and fellow workmen, at last the octopus is closing his tentacles about the living bodies of our women and children. Like a gloating vulture, the hireling of the company is waiting to fill our valley with the sighs and sobs of starving people...if we are to starve let it be in the sun with God's pure air around us. If we are to die let it be fighting like the slaves of old Rome. I stand, like Moses, for my people. (Jones, p.193)

\footnotetext{
${ }^{10}$ Jones, Cwmardy, p. 188. The situation is analogous to that driving the Tonypandy debacle.
} 
Beside this resonance with images of slavery, the text provides a panoramic view of events, relating the stance adopted by the mine owner, Lord Cwmardy and his manager at the Big House, who agree that the miners will 'assuredly strike' but that with no organisation, no money and no leaders, they will not be able to strike for long. To ensure the continued lack of leadership, the management consider whether Ezra Jones, an influential old mining leader, can be 'bought off', but in concluding that he is 'incorruptible', they are anyway assured in the range of their influence in every other realm (Jones, p. 200). It is thus made clear not only that the miners have no real choice but to strike and that this is the only effective method of exerting influence open to them, but also that the contest of wills is to be utterly uneven from the start, as democratic mechanisms are entirely manipulated by those in power. The trusting integrity trained into the ordinary worker by elementary religious and state education, mortally endangered as he is by his conditions of work ${ }^{11}$ is pitted against the crude commercialism of the captains of industry.

The strike action deepens with confrontations between mine officials (designated 'blacklegs' and 'scabs' by the miners) and striking miners. In continuing to work, the mine officials seriously undermine the effectiveness of the strike, a strike which the men are only able to maintain at the price of great privation to themselves and their families. Attempting to exert further control over the situation, the mining company call in the police. The utilisation of a police presence in such a context has deep political as well as legal implications, as the text makes clear, with inferences for jurisprudence and law never fully addressed.

In Lewis Jones's text, the use of the police force against them bewilders the workers: ${ }^{12}$ As the omniscient narrative comments (Jones, p. 221): 'What they failed to understand was why, when the advantage was with them, ${ }^{13}$ the police should be placed at the disposal of the owners'. The police presence proves menacing as, with little provocation, batons rain down 'with smashing regularity' on the heads of the miners whilst 'posses of uniformed men' parade through back lanes and 'burst their way' into houses at will. The offence is compounded by inaccurate and propagandist newspaper accounts portraying the striking men as hooligans and looters subjecting the police to wild attack and forcing the police to draw batons in self defence. ${ }^{14}$ The politically acute Ezra and

\footnotetext{
${ }^{11}$ The worst explosion in British mining history occurred on October $14^{\text {th }}, 1913$, when 439 miners were killed at Senghenydd in South Wales.

${ }^{12}$ In Tonypandy itself, some acknowledgement of correct process would have been signalled by a reading of the Riot Act at some stage prior to the deployment of aggressive force, but according to the record, this did not occur.

13 'them' being a reference to the owners.

${ }^{14}$ According to first-hand accounts, an unrepresentative group was involved in perpetrating some damage, nevertheless it seems that troop and police action in Tonypandy was wholly disproportionate, with striking miners 'charged' with fixed bayonets. In the clash with police on $8^{\text {th }}$ November 1910 , one man, a bachelor collier, Samuel Rays, died as a result of head wounds. The inquest jury, after being advised that if they found
} 
Len understand that a report in the newspaper will be perceived as 'truth' and that such 'evidence' will be significant for the law:

What you see in black and white is truth and you must always believe it...Right has always been, and always will be, determined by might. There can never be one law that is at once good for the tiger and the lamb. Neither can there be one law that binds together the interests of workmen and owners[...](Jones, p.231)

In an attempt to overcome the impasse, the striking men promise that the officials and 'safety men' will be guaranteed free movement provided the police are withdrawn, but a manager claims that this would be 'impossible', that the matter was 'entirely out of [their] hands' and that 'the police are under the control of the authorities and have nothing at all to do with the company'. That this is a debateable assertion is however again acknowledged by the text. The status of the call upon the services of the police is recognised as pivotal to the confrontation between capital and worker. Claiming that the police are under the 'control of the authorities' implies the political neutrality of the management in their deployment, whilst signalling that such intervention on behalf of representatives of the state is entirely necessary to a policy of containment. In discussions with Union activists, Len and others divine that the status of the police deployment is a truly significant issue.

\section{THE LEGAL RECORD}

The particularly harsh period of global struggle in the early part of the $20^{\text {th }}$ century was characterised by the great depression affecting individual fates and fortunes on both sides of the Atlantic. Industrial Wales had in fact provided a sensitive barometer of erratic world markets for decades, forming a crucible for the politicisation of the workforce from the mid $19^{\text {th }}$ century. In the coal industry, the volatile impact of the market was passed on to the miner through the mechanism of the sliding scale, so that the rise and fall in prices was reflected in the weekly wage. ${ }^{15}$ On the political landscape, struggles were occurring with

\footnotetext{
that his injuries were caused by a policeman's truncheon' they would also have to decide if 'the police were justified in the action they had taken in using force to repel force for the purpose of preventing disorder', decided that it was not 'sufficiently clear' how the injuries 'caused by some blunt instrument' had been received. (see Smith, p 99).

${ }^{15}$ Throughout the $19^{\text {th }}$ and early $20^{\text {th }}$ century, wages in the mining industry were linked to market prices of coal in a 'sliding scale'; a volatile and unpredictable measure
} 
momentous implications for the law, yet if one looks to the legal record of the period, hints of this vast world are halting ${ }^{16}$

Being educated into the law, one tends to accept its major structural organisation as integral, but viewing the law through the prism of fiction promotes fresh consideration of such structures. For the ordinary citizen it may seem strange and perhaps even a kind of cultural failing that such struggles are scarcely represented on the legal record, or indeed reflected upon in legal theory. In dramatising the life of this industrial community Jones depicts the relationship between private and public life in order to explicate the systematic failures of public process. Considering the three events identified in the text, the formal hearing of an inquest by its nature would be unlikely to gain a place in the legal record. Given its identity as a tribunal of fact, the mechanism for enquiry into issues of justice is minimised and where the representational power of any party is at all compromised, so too is any such mechanism. The deployment of police (as well as troops) in the context of industrial action, though of deep potential significance to the polity, may be characterised readily as a response to impending civic disorder, a practical and essential containment measure, dealing only with a threat of violence and of little lasting significance to the legal record. Similarly, as the text by Jones implies, the displacement of individuals like Len (politicised citizens capable of exposition and articulation of faults in the status quo) into the marginalising system of criminal process, consigns their reasonable, legitimate concern to ignominy and obscurity, 'naturalising' them as criminals. Though all three juristic events are significant, as part of an organic critique of the law, the basis of police deployment in particular is most contentious. Inquest findings may be partial as a result of the influence and prejudices of local individuals, as may the 'criminalisation' of political activists. But the use of forces, and the question of who finances them, is an even broader juridical issue, going to the heart of the State and law. Any attempt to navigate the processes of history via the processes of law will prove problematic. Though the early $20^{\text {th }}$ century saw some legislation and some caselaw in

\footnotetext{
${ }^{16}$ For example, the story behind the 'minimum wage' is epic. From 1911, Mining Federation delegates voted for strike action unless the principle of a minimum wage was conceded by the coal owners. By a massive majority of four to one, the membership voted to take strike action at the end of February, 1912. This was the first time a coal dispute affected the nation as a whole. By March $1^{\text {st }}$, over one million miners were out on strike. From other sections of workers all around Britain there was substantial support for action taken to secure a fixed minimum wage. The dispute lasted six weeks; it was called off by the Federation when the then Liberal government promised to introduce protective legislation on pay. Yet once the Government secured the miners' return to work, it was decided that there would be no actual minimum wage figure in its Bill. Another ballot saw mineworkers voting by nearly 54 per cent to continue the strike, but as this fell short of the necessary twothirds majority, a return to work was agreed and a compromise Minimum Wage Act appeared in 1912. Without the entrenchment of additional employment securities however, the minimum wage itself proved a poor source of stability.
} 
relation to industrial issues, this was piecemeal, given the scale of the issues, with the caselaw often normalising the prevailing hegemonic view. Of course the key purpose of the legal record is to identify significant practical legal rules and the purpose of legal history to formulate a coherent account of the development of principle. But the fact that the record both disregards events and crystallises them into a principle utterly in denial of the wider context, fuels the mutual alienation of subject and law and is in itself a cultural and hermeneutic phenomenon of note. As already indicated, Jones's fiction dramatises the struggle in Tonypandy in 1910 when striking miners were suppressed both by a police and then army presence. The army presence was the most gross insult - and threat - to the working community, revealing the taking up of a clear position by the State in relation to these particular citizens. The use of police as well as troops signalled this same message. As Smith (1999, p. 104) recounts:

Churchill was reluctant to accede to the somewhat intemperate demands of the local magistracy and judiciary who had been sending out distress signals as early as 2 November 1910. They were anxious for a military presence to overawe the miners on strike in both the Cynon and Rhondda Valleys (in separate disputes)...the troops, as well as over 1000 police, were, in essence, an army of occupation...the troops ensured that all mass demonstrations against blackleg labour would be controlled and thereby rendered ineffective...their presence prevented the mass picketing which the leaders of the strikers had seen as their only real hope of an early victory...the defeat suffered by the men of the Cambrian Combine was, in the eyes of the local community, attached directly to the state intervention authorised by Churchill.

Note that it was said that a probable key purpose of the deployment was to control and render ineffective the use of industrial action. Crucial to the issue of the deployment of forces and the status of that deployment is the question of whether there was any real threat of mass violence. Certainly the local population and social commentators believed that the small outbreak of violence which did occur was in response to ill-treatment and violence and was anyway perpetrated by an unrepresentative group. ${ }^{17}$ Yet, though so central to the annals of Welsh industrial history, subtle differences in accounts of the events only serve to highlight the strongly interpretative element present in general - as well as legal - history. In addition

\footnotetext{
${ }^{17}$ See Smith, p. 116. This point is made by Jones's narrative version.
} 
the struggle bears scant recognition in general British historical accounts of the period, even those with a social and political remit. ${ }^{18}$

\section{THE CASE OF GLASBROOK BROTHERS}

In relation to this particular period, the variable recorded histories and the prompts of narrative fiction outlined above drive scrutiny of formal precedent in relation to the use of police. It is not until a strike of 1924 in a neighbouring coalfield that the common law principle underlying the deployment of police in such circumstances is discussed, in much diluted form, with the case of Glasbrook Brothers $v$ Glamorgan County Council $(1925)^{19}$. As already mentioned, even taking into account the legislative developments during the early decades of the $20^{\text {th }}$ century the 'legal record' provides little hint of the vast human story unfolding throughout, and this case is an oblique encounter for the working person, given the fact that the workers at the heart of the dispute giving rise to the case were not participating litigants. Thinking from the point of view of the working citizen, searching for some clue, some pathway through the annals of legal precedent, a clue which might acknowledge the facts of their recent history, the case of Glasbrook Bros presents an odd visible landmark in the voyage to law, and arguably illuminates Jones's turn to instructive fiction, recourse to law and politics proving nugatory. Indeed it may be that Jones, writing in the late 1930's, recounts the events of Tonypandy (in fact occurring in 1910-11) and compresses them alongside an emphasis upon the legality of police deployment (and a query concerning the fiscal support for such deployment), with a consciousness of the stance of this case, occurring as it did in the 1920's. To compress the message of the unfolding decades was to elucidate the ideological challenge of the times.

To lawyers, the significance of the case lies in its doctrinal importance in the law of contract. The point at issue is whether fees are payable where the police authorities provide a policing service over and above that required by their own assessment of the extent of duty in the need to preserve order. For a contract lawyer, the case is a question of commerce - of whether, if

\footnotetext{
${ }^{18}$ A brief survey of histories has borne this out. For example, the social historian Trevelyan (1986) provides a timeline which refers to events in Wales and includes the fact that miners struck for a minimum wage in 1912, but the Tonypandy events are not recorded.

${ }^{19}$ Glasbrook Bros v Glamorgan CC (1925) A.C. 270. The key ratio of the case stated 'Although the police authority are bound to provide sufficient protection to life and property without payment, if in particular circumstances, at the request of an individual, they provide a special form of protection outside the scope of their public duty they may demand payment for it'.
} 
at all, contractual 'consideration' had been provided for the claim to fee and the relationship of that concept to the exercise of duty. ${ }^{20}$ For this reason, the case of Glasbrook Bros is found in textbooks on the law of contract, rather than those on the law of employment or indeed where the relationship between politics and law is most actively debated - in jurisprudence. Insofar as law may be treated as a factual record of significant legal mechanisms and significant legal events we might expect to be able to gain a fairly enriching insight into an event or period of legal consequence from the legal record. Even taking account of the constraints of the historical moment, the claims of law - to forensic precision, detachment, objectivity, formal consistency, substantive flexibility and so on - might nevertheless reveal some sense of the immanent issues. Thinking about these issues in relation to the specific case of Glasbrook begs questions on many points of legal convention, from the relationship between political and legal philosophy to the notions of social, civic, and labour contract the very structure and concept of contract law itself. Yet, throughout the law of contract, the case is glossed as a simple precedent regarding the boundary of contractual and noncontractual duty.

The case arose as a result of a national miners strike, in circumstances bearing a significant relation to those concerning Lewis Jones. At a group of collieries near Swansea, the manager at Glasbrook Bros mines responded to unrest and resistance ${ }^{21}$ to the call to return to work by applying for police protection for the colliery and insisting that ${ }^{22}$

It could only be efficiently protected by billeting a police force on the premises. The police superintendent was prepared to provide what in his opinion was adequate protection by means of a mobile force, but refused to billet police officers at the colliery except on the terms of the manager agreeing to pay for the force so provided at a specified rate.

The county council employing the police force subsequently brought an action against Glasbrook Bros for payment of the fee, which had been resisted for want of consideration. The ratio decidendi in the House of Lords was that 'there was nothing illegal in the agreement, nor was it void for want of consideration'. ${ }^{23}$ In standard textbooks on the law of

\footnotetext{
${ }^{20}$ Questions concerning the doctrine of consideration are much beloved by contract lawyers and indeed the doctrine has a deeply convoluted narrative history of its own involving a complex excursus upon the relationship between payment, deed and bond.

${ }^{21}$ (a refusal to return to work in compliance with a national agreement to end strike action, picketing with some unrest, including pulling a safety man off his bicycle, and a declared resolve to 'get all the safety men out')

${ }^{22}$ From the summary of facts, paragraph one Glasbrook Bros v Glamorgan County Council [1925] A.C. 270; 1924 WL 19840 (HL).

${ }^{23}$ The court at lst inst and the CA had reached the same conclusion as the HL
} 
contract, the case is reported as a straightforward precedent on the doctrine of consideration. Viscount Cave, delivering the judgment, outlined a firm account of legal principle: ${ }^{24}$

My Lords, the practice by which police authorities make a charge for 'special services,' that is to say, for services rendered outside the scope of their obligations, has been established for upwards of sixty years and is constantly followed by every police authority in the country with the approval of the Secretary of State; and it is difficult to understand on what grounds it should now be treated as illegal.

To explain how an opposing model of the principle might be fashioned, Viscount Cave quoted Lord Atkin ${ }^{25}$ who had stated

Either they were performing this public duty in giving this protection asked for, in which case I think they cannot charge, or, which no-one suggests, they were at the request of one individual doing something which it was not their duty to do, in which case it seems to me both public policy and s10 of the county Police Act 1839, make the contract illegal and void. ${ }^{26}$

Viscount Cave deploys this argument in order to refute it, positing a failure, on the part of Atkin LJ, to recognise a distinction between a 'duty' and a 'power' 27

With great respect to the learned Lord Justice I am disposed to think that this reasoning rests on an ambiguous use of the word 'duty'. There may be services rendered by the police which, although not within the scope of their absolute obligations to the public, may yet fall within their powers, and in such cases public policy does not forbid their performance. I do not understand the reference in the above passage to s 10 of the Act of 1839 .

It is unlikely however that the great Lord Justice Atkin was really guilty of such an oversight. On one reading, Atkin is merely applying a particular technical approach to the issue in the law of contract - if duty extends to these circumstances, there is no basis for contract, if no duty extends but money is paid, the contract is illegal and void. But characterising it in this particular way may also betray the political position of the judge. For arguably a strict duty/no duty account of the principle envisions a world in which circumstances either clearly

\footnotetext{
${ }^{24}$ Glasbrook Bros, 1924 WL 19840 p.5.

25 in the Court of Appeal.

${ }^{26}$ The Police Act 1839, s. 10 stated 'And be it enacted, that all Chiefs and other Constables appointed under this Act shall be restrained from employing themselves in any office or Employment for Hire or Gain other than in the Execution of their Duties under this Act' ('The Police Act: An Act for the Establishment of County and District constables by Authority of Justice of the Peace'; CAP XCIII, Pickering's Statutes Vol LXIX 2 \& 3 Vict 1839 (511).

${ }^{27}$ Glasbrook Bros, WL 19840, P5.
} 
and unequivocally call for the necessity of police intervention - as a matter of duty, in their role as mediators of state and public peace, or they do not, and contract here is 'illegal' and 'void on grounds of public policy' because of the shadow of a contract for mercenary services. Conversely, once Viscount Cave posits a world in which police may render ${ }^{28}$ services...which, although not within the scope of their absolute obligations to the public, may yet fall within their powers and in such cases public policy does not forbid their performance

he is evading the issue foreshadowing such a model - the prejudicial use of police services as a coercive force. $^{29}$ Where once the role of the police moves from that of public protection to industrial strong arm, an 'ambiguity' indeed arises around the notion of 'duty'.

For the discussion here is one of an elemental struggle for power. The capital power of the industrialist (in his manipulation of contractual terms) cannot be challenged by the poor labourer alone, it can only be challenged by the collective entity of the workforce. And confirming that a garrison of police can effectively be hired to challenge such a workforce confirming that such a contract can sound in law - is a deeply political finding and not simply an interesting doctrinal point on consideration. There is perhaps the slightest intimation of this point in the rhetoric employed by Viscount Cave, in his statement that 'public policy does not forbid ${ }^{30}$ the performance of such contracts. This surely betrays at least a subliminal awareness of the political sensitivity of the issue - signalling that, whilst there may be no formalised veto, there is surely a concern.

The dissenting judgment of Lord Carson was not an assertion of concern over such civic principles. Quite the contrary. Lord Carson was concerned to uphold the right of individuals ('individuals' here relating to the property-owning classes only) to take steps to protect life and property ${ }^{31}$ and on the facts concluded that the supply of police was necessary to the preservation of the pit. He did not dispute the proposition that the doctrine of consideration could be brought into play in such a case, rather he contended that it had not come into play

\footnotetext{
28 Ibid.

${ }^{29}$ Though the police force, as the Metropolitan Police Force (the 'Peelers') was established in 1829 in part as a response to the movement of large populations into urban, industrial communities, with the attendant risk of disorder, it was with the stated principle that their function was the protection of the public against 'criminal' types.

${ }^{30}$ Italics added.

${ }^{31}$ Glasbrook Bros, p 12 'I should like to supplement these statements by one further observation - namely, that it is not in the power of the executive through the Secretary of State or otherwise to limit the rights of the subject in obtaining such protection for life and property and that any attempt to do so would be absolutely unconstitutional and illegal'.
} 
on the facts of this particular case, judging police involvement on the large scale requested by the manager necessary to induce the safety men to continue pumping the mines.

The second dissenting judge, Lord Blanesburgh, similarly believed that the police presence was necessitated by duty. His examination of the evidence focussed upon the fact that the lower courts had failed to challenge the police superintendent's assertion that sufficient police protection could have been afforded without a police garrison, but merely a police presence. According to Lord Blanesburgh, though such an opinion was no doubt formed in good faith, it was a mistaken opinion, flying in the face of evidence that the safety men would not have continued work without a full garrison. At issue here was not so much a suggestion that violence was truly objectively imminent (for the superintendent believed the situation to be perfectly containable with a minimal police presence). Rather it was that, since the safety men felt sufficiently intimidated to doubt whether they should continue work, then there was sufficient subjective apprehension to interfere with the continued labour of the safety men. This formed the basis of Lord Blanesburgh's dissent. Yet in effect this is not a focus upon a threat of violence or a direct threat to property. It is rather about the extent to which police involvement is justifiable in the maintenance of industrial property, coloured as it is by a perceived threat. For on one view we may say the primary function of the safety men was to carry out essential work to prevent flooding of the mine in order to preserve its functional capability. On another view, they functioned as blacklegs, ${ }^{32}$ deeply undermining the efficacy of strike action. On yet another view, the withdrawal of labour - the cessation of coal production, justifiably could be treated as a separate issue from the maintenance of property. On whatever reading, the opposition of property to labour is much more politically charged than is indicated by a merely technical debate about the doctrine of consideration. For the men involved, the 'placing of police at the disposal of the owners' (as Jones expresses it in Cwmardy) identifies the police as something other than community servants, their role and their master the fundamental gauge of the link between public law, private law and the very concept of the rule of law itself, in a state where, apparently, 'right' may be determined by 'might'.

\section{HISTORIOGRAPHY AND THE LABOUR CONTRACT}

\footnotetext{
${ }^{32}$ Lewis Jones's text (p. 216) suggests that the 'officials' brought in to 'keep the pits in working order' are more numerous than needed for the purpose.
} 
If one accepts a key element of Jones's account - that principled people are denied justice, are criminalised and brutalised - and thereby politicised - one is stimulated to consider the legal framework underlying such a process. The novel brings force to some fundamental issues - to the absolute linkage between labour and survival, power and coercion; the need for authentic access to the political and legal mechanisms for change. The lived, subjective experience of the privations leading to the dramatisation by Jones and a case like Glasbrook Bros is one of unremitting hardship. The legal principles and legal record bear scant witness to these facts and we may therefore consider the very structure of those principles, of the historiography of law and the labour contract.

Somewhat surprisingly, texts tracing the history and origins of the law of contract pay scant attention to the doubtful foundation of the labour contract. ${ }^{33}$ With classical contract law providing a largely normalising role for the case, one might expect Glasbrook Bros to appear again and more discursively in the texts of labour law perhaps with more consciousness of its political significance. It is after all - quite apart from being an intriguing sight of the nature of the labour contract of the police themselves - a case touching upon the engagement between a containment force and the very function of industrial action as a means of negotiating the labour contract. Yet though a central precedent in the law of contract, learned by all British undergraduates in law, the case is absent from the texts on labour law. Though Kahn-Freund (a seminal writer on the political and coercive context of labour relations) readily recognises for example (1983:24) that:

It is necessary for the law to see relations of subordination in terms of co-ordination, that is, an act of submission in the mask of a 'contract,' because this is the fiction through which it exorcises the incubus of "compulsory labour"

- there is no mention of Glasbrook Bros in any part of the book, ${ }^{34}$ Especially surprising is the failure of textbooks on Labour Law to trace the longstanding role of the law in the history of labour itself $f^{35}$.

\footnotetext{
${ }^{33}$ Consider for example, Atiyah (1995) Gordley (1991) and Collins (1993). It is in the feminist critique of the models of labour contract, domestic contract and social contract provided by Pateman (1988) that the link between classical rhetorics and doctrines of freedom and coercive practice, is explored.

${ }^{34}$ Nor is it mentioned in Labour Law in Britain, ed. Roy Lewis (1986) nor even the comprehensive Deakin and Morris (1998).

${ }^{35}$ In mediaeval Europe, serfdom of course imposed a peonage between the land, the labourer and his Lord as a matter of birth rather than bargain. According to Keen (1990) one of the side effects of the plague in the 1300's was for landlords to assert with renewed vigour their rights to dues and services from tenants, as the value of such fees and work was heightened by the collapse of rental income from freemen cut down by plague. This formed a contributing factor in the Peasant's Revolt of 1381. As Keen explains (p. 42-3):
} 
Though the issues as indicated by the case therefore appear to have been elided both in the courtroom and in the text, the 'incubus' of 'compulsory labour' is, as Kahn Freund indicates, ever present. For the labour contract to have any genuine connection to the notion of contract effective collective bargaining and where necessary, action, is crucial in that it provides some cogent meaning to the idea of a meeting of minds by a levelling of powers. Ultimately ${ }^{36}$ the collective agreement, when it is reached, may simply be an agreement to accept defeat, to return to work in virtual acceptance of the miserable terms imposed by the mine owners. It is a collective 'bargain' in name only.

It may be argued that the case has little to do with labour law. Even the labour of policemen ${ }^{37}$ is oddly circumvented as a commodity of oblique significance to the question of consideration. Yet the case is of profound significance to the issue of labour. For not only is the issue of the deployment of police labour deeply political and therefore significant to the ethics and integrity of the rule of law. The deployment of such labour is of even greater significance when it relates to the withholding, and ultimate coercion, of labour by others. Thus the narrative 'truth-space' claimed by the legal record and the status accorded to this

There was also a rudimentary ideological level to the revolt. It is perhaps most marked in the demands of the rebels for 'freedom', for the abolition of serfdom and equality of status before the law...Langland says that revolutionary friars were preaching a kind of primitive communism.

A significant feature in the provocation of the peasants was the utilisation of legal principle in their oppression, with the enactment of the Ordinance of Labourers in 1349 followed by the Statute of Labourers in 1351. A development of great significance in the history of the labour contract, this statutory move crystallised the link between labour and politics[...]The object of the act was clear and straightforward, to hold up the economic weather by protecting the interests of lords and employers.

This formed a key issue in the manifesto of the Peasant's Revolt, where Wat Tyler demanded that 'No one should work for any man but at his own will, and on terms of regular covenant' - According to Keen the demand was just as revolutionary and pertinent as it suggests, aiming 'A clear and direct blow at the clause in the Statute of Labourers that gave a lord a preferential hold over his men's labour and demanded the freedom to negotiate on wages it inhibited'. Clearly demonstrating a belief in the idea of security of contract - covenant - and in the intrinsic liberty indicated by the expression of 'will', the demand reflects a very modern and idealistic conception of contract, perhaps already tapping into the myth that would declare the defeat of status by contract centuries later.

${ }^{36}$ As was the case with Glasbrook Bros.

37 Note that Deakin and Morris (1998, p.186) do however explain the modern position of the police qua 'employees' or 'workers' - Police officers are excluded from most of the protective statutory provisions available to 'employees' or 'workers' - 'The balance of judicial opinion is that police officers do not have contracts of employment, although the terms in which the statutory exclusion is framed leaves open the possibility that they do. In constitutional terms, police constables are regarded as 'independent officers' capable of exercising legal powers derived from the nature of their office; for this reason, it was held that for the purpose of vicarious liability in tort they were not the employees of the relevant police authority [Fisher v Oldham Corpn [1930] 3KB 364'. These ambiguities, with an utterly selective deployment and displacement of concepts deriving from contract, tort and administrative law only serve to demonstrate the politically nuanced nature of this arm of state control. It must be noted in addition that members of the profession can pursue discrimination rights, are entitled to written particulars of their terms and conditions, have minimum notice and redundancy rights and are within the scope of the Working Time Regulations in so far as is practicable. In recent years (see - http://news.bbc.co.uk/1/hi/uk/7409679.stm) they have been active in pursuing the question of the right to strike, though Edwards (2010) reports that this may be subject to the termination of lucrative overtime payments. 
doctrinal significance effectively subsumes the narrative possibilities to be found in the broader historical record. And it is perhaps at this juncture that narrative - such as that produced by Jones - must be deployed in order to reinstate the profound truth of lived experience.

\section{LEGAL AND POLITICAL THEORY AND THE LABOUR CONTRACT}

In reading of the struggle to win a 'living' wage and achieve a degree of autonomy in the regulation of their working lives, the travails of the miners in Cwmardy - especially where the coercive forces of the state are brought to bear - are a vivid reminder of how very thin is the mask of contract upon a face of 'compulsory labour'. Given this context, the analysis of such forces provided by Marxist theory must have seemed compelling and wholly logical. As is well known, Marx addressed the issue of the relationship between labour, the living wage and coercion many times. As he stated in his early lectures ${ }^{38}$

Wages are only a special name for the price of labour, for the price of this peculiar commodity which has no other repository than flesh and blood.

For the workers of South Wales, the literal truth of such analysis no doubt presaged hope that wider understanding of their predicament was at hand. Yet even today, though the philosophical impact of the Marxist position has been explored by many writers, this relationship, between the notions of labour, coercion and payment, remains resistant to full exposition. One scholar willing to embark upon an engagement with the implications of the spectre of coercion is Cohen and it may be helpful at this point to track some aspects of Cohen's discussion (Cohen, 1997) in order to derive some broad insights into the discourse discoverable in relation to labour and coercion. Reminding us (Cohen, 1997, p. 429) that, according to Marx:

a member of a social class belongs to it by virtue of his position within social relations of production. In keeping with this formula, Marx defined the proletarian as the producer who has (literally or in effect) nothing to sell but his own labor power

Cohen suggests a clear inference, that for Marx, the worker 'is forced to sell his labor power (on pain of starvation)'. Cohen sets out to explore the putative 'truth' of the claim that workers are 'forced' to sell their labour power, in the process examining possible 'leftist' and

\footnotetext{
${ }^{38}$ Quoted in McLellan (2000, p 275).
} 
'rightist' responses to the claim. ${ }^{39}$ A central plank of Cohen's discussion proposes that a worker is

forced to sell his labor power in the presently required sense if and only if the constraint is a result of standard exercises of the powers constituting relations of production...The relevant constraint must reflect use of economic power, and not, moreover, just any use of it, but a standard exercise of it. I do not yet know how to define "standard", but it is not hard to sort out cases in an intuitive way. If, for example, a capitalist forces people to work for him by hiring gunmen to get them to do so, the resulting constraint is due to a non-standard exercise of economic power ...a philanthropic capitalist might be willing to transfer large shares in the ownership of his enterprise to workers...that would not be a standard use of capitalist power.

Already this juxtaposition of a constraint deriving from economic power alongside the notion of a standard exercise of such power is less straightforward than it might appear. When illustrated by the extreme examples of what would not comprise a standard exercise of such power - the use of hired gunmen on the one hand and a philanthropic gift on the other - the examples only serve to demonstrate the utterly pivotal importance of the status accorded to the deployment of a state force. Cohen is attuned to the possibility of state involvement in coercive phenomena ${ }^{40}$, yet, though one might expect this discussion to lead naturally into some recognition of the possible relevance of coercive 'state officials', no such discussion ensues. Instead, Cohen is diverted into a detailed analysis of the notion of coercion, its content explored by comparing the alleged predicament of the coerced worker with the imagined predicament of persons locked into a room with limited opportunity for escape. ${ }^{41}$

Arguably, such an analogy only serves to emphasise the degree to which abstracted examples of a dilemma diverge from their real counterparts, where the freedom to 'stay' or 'escape' is very much affected by the actual presence of coercive forces. And though workers may elect

\footnotetext{
39 Ibid. Cohen's hypothesising of such responses, and his own counter arguments in relation to such hypotheses, though intriguing, do not demand attention in this particular discussion

${ }^{40}$ Cohen, p. 431.

${ }^{41}$ Ibid....'For capitalism requires a substantial hired labor force...does [this] refute the claim that most proletarians are not forced to sell their labor power? I think not. An analogy will indicate why. Ten people are placed in a room the only exit from which is a huge and heavy locked door... whoever [uses the key first may unlock the door and leave the room but photoelectric devices will only allow one person to exit. At least nine people will remain in the room]. Now suppose that not one of the people is inclined to try to obtain the key and leave the room. Perhaps the room is no bad place, and they do not want to leave it. Or perhaps it is pretty bad, but they are too lazy to undertake the effort needed to escape'.
} 
to 'escape' or 'walk away' from the constraint that is their labour, the social, economic and geographical conditions make such choice near impossible for most. ${ }^{42}$ A myriad of other reasons are likely to inhibit them from doing so, not least concern for holding fast to existing personal bonds, as the intimate community of Cwmardy implies. ${ }^{43}$ As one might surmise and as Cwmardy demonstrates however, such 'collective loyalty' does not tend to be the force driving attempts at liberation, rather such cohesive relationships are in part a result of the dearth of choices available individually and collectively - they are not the fruits of 'choice' in our usual understanding of the term, rather they are the fruits of absolute reason in the absence of 'true' choice. Cohen's model posits a somewhat 'automated' scheme, where escape by one inmate activates a sensor which locks the remaining inmates inside. However, nowhere does Cohen recognise the direct relevance of the analogy to the use of coercive forces: the problem of lack of choice is not in fact a merely mechanical or numerical one. And the irony here is that 'collective bargaining' is dependent, for its effectiveness, on individuals staying within the unit ${ }^{44}$ Yet Cohen elides the clear relationship of the analogy to collective action and collective bargaining, again becoming sidetracked into a discussion of the possibility of 'co-operatives' as a means to freedom, whilst failing to see the clear significance of the phenomenon of unions as a means of collective power. Though he concludes (Cohen, p. 442) rather weakly that:

...it might be, though false, nearly true that the overwhelming majority of the proletariat are forced to sell their labor power...because there are virtually no exits available at any given time

Cohen does not recognise the relevance of the use of compulsive forces to this 'virtual' lack of exits. Nor does he address a key issue linking labour with compulsion - that of whether

\footnotetext{
${ }^{42}$ Though emigration to escape poverty was a clear phenomenon of the period, the mining communities of South Wales were themselves already the product of migration - from the poverty and poor employment opportunities of rural Wales. The industrial areas were typified by tiny terraces of houses containing large struggling families. For most, movement of the family on any scale must have seemed an impracticable dream.

${ }^{43}$ Cohen (p. 433) touches upon this possibility at a late stage in his analysis:

...human motivation shows that sometimes people care about the fate of others, and they sometimes have that concern when they share a common oppression...a fourth possible explanation of the absence of attempt to leave now suggests itself. It is that no one will be satisfied with a personal escape which is not part of a general liberation...we can conclude...that although most proletarians are free to escape the proletariat, and, indeed, even if every one is, the proletariat is collectively unfree, an imprisoned class.
}

\footnotetext{
44 and indeed the 'real' and dramatised men 'stay down' in the mine as a response to the usual 'lock-out' imposed
} by industrialists). 
the 'deal' available offers meaningful payment for the work. ${ }^{45}$ For 'subsistence' wages limit freedom of action in a practical sense - affecting the degree of energy available to approach the exit. The fact that this essay by Cohen provides an extensive exploration of the philosophical links between the labour contract and coercion, yet fails to provide recognition of the dilemma in a form more potent than that it might be 'nearly true' that workers are forced to sell their labour power, goes some way to explaining the resistance of the concept, its vulnerability to dilution and reconstitution through abstraction.

Thus philosophy as well as law may fail to give recognition to the depth of the dilemma and history in its turn - as well as philosophy - contributes to the construction of these 'realities' in law. Modern historiographic accounts of the journey from feudalism to capitalism, in particular in relation to the labour contract, are a recognisable strand in the background to the process of narrative elision and uncertainty, adding to the complex, layered visions of labour discoverable in politics, law, fiction and the media. Holton (1981) for example identifies a whole range of theories. ${ }^{46}$ Differing interpretations of this crucial historical pathway - the transition from feudal to capital - are often grounded upon differing criterial perspectives and evidential origins; such uncertainties assist in the successful promotion of certain ideological assertions, not least the myth of equality underlying the idea of the labour market and contract. ${ }^{47}$ Writers such as Banaji ${ }^{48}$ set out to argue that such assumptions fail to give

\footnotetext{
${ }^{45}$ As well as whether there is a meaningful correlation between labour expended by worker and capital realised, and accepting that the capitalist must provide outlay costs and, in taking capital risks, has claim upon certain proportion of capital.

${ }^{46}$ Holton (1981) concentrates an entire study upon the divergence of views amongst academics in the debate over the transition from feudalism to capitalism in Europe. Holton reviews the difficulties inherent in Marx's own changing accounts of the transition:

(p. 836)[...]divergences[...]stem in part from the incomplete and rather unsystematic comments that Marx made on this specific historical problem. These range from the bald propositions of The Communist Manifesto, through the suggestive sketches in The German Ideology and Pre-Capitalist Economic Formations, to the sustained discussion of "primitive accumulation," and "merchant capital" in Capital. Such comments, though highly suggestive, are nonetheless far from definitive theories free from ambivalence

Holton then explores the theoretical positions of the major contributors to the debate, quoting SweezyWallerstein pursuing an 'exchange relations' perspective, where the dynamic for feudal decline and capitalist development is the influence of international trade and forms, a process 'external' to feudalism, alongside mercantile development; Dobb, Hilton and Brenner pursuing perspectives expressing Marx's teleological view of man as capable of growing and overcoming alienating social relations, wherein feudalism declines because of its inherent inefficiency, coupled with the weakening effects of class struggle between lords and serfs and the overwhelming effect of agrarian transformation, and Anderson's view, where a Renaissance vision of man - as essentially civilised and self-motivated - is reclaimed as part of a process of capital success wherein (856) "the classical past awoke again within the feudal present to assist the arrival of a capitalist future".

${ }^{47}$ See Holton, p $862-[\ldots]$ 'some authors approach...feudalism in terms of generic economic criteria... while others see it far more in terms of particular genetic characteristics defined in terms of the interpenetration of economic, legal, and political criteria, unique to feudalism... a second dilemma concerns the relationship between teleological aspects of theoretical reasoning and the problem of scientific verification'[...]

${ }^{48}$ Banaji (2003). Definitional difficulties abound:
} 
recognition to the primacy of the analysis put forward by Marx whereby the notion of 'free labour' was contested.

Banaji's discussion focuses very much upon the issues of consensuality and voluntariness or the lack thereof - in the labour contract. ${ }^{49}$ Dramatically noticeable however, both in the review of the differing theories concerning the history and origins of the labour contract put forward by Banaji and in his own synthesising assessment, is the failure to recognise that payment around the bare subsistence level makes the distinction between the wage contract and virtual labour slavery disappear to vanishing point. The submersion of notions such as sharecropping and labour tenancy into the concept of the wage contract is after all not so very controversial - 'wages' may take different forms ${ }^{50}$.

Given little or no mention in the theorisation of texts devoted to labour law, it transpires that the issue is also given minimal treatment in texts concerned with Public Law, yet the payment and deployment of a state force in the midst of industrial action lies on the very nexus - the boundary, howsoever imagined, between public and private law, pivotal to the relationship between state and citizen and thereby to the very identity of these branches of law - of what law is. That this is in turn determined by economic relations was a fact divined by Engels as well as Marx $^{51}$

...'If the state and public law are determined by economic relations, so, too, of course is private law, which indeed in essence only sanctions the existing economic relations between individuals which are normal in the given circumstances. The form in which this happens can, however, vary considerably. It is possible, as happened in England, in harmony with the whole national development, to retain in the main the forms of

(p. 74)... the upshot of their stark dualities is that Brass and Ramachandran both subscribe to a liberalindividualist notion of wage-labour as essentially free labour, labour based on the 'consent' of the individual worker and the free bargain that embodies that 'consent'.

${ }^{49}$ His survey takes account of studies of bonded labour in India, of debt peonage in Mexico, p. 79 of the 'feudal remnant in the governance of American labour in the nineteenth century' (p. 77). Referring to Orren's discussion of master and servant law, of 'the position of nineteenth-century English wage-earners who faced criminal sanctions for breach of contract' Banaji concludes that, while the organisation of labour in a system of capital accumulation implicates forms of exploitation beyond the presumptively normative free labour contract and the only real freedom workers possess under capitalism or any system of domination is their power of resistance...

${ }^{50}$ Note for example the intimate tie between industrial urban tenancies and the immediate industry itself; also, of tied markets, such as 'tommy shops', where workers were forced to buy weekly necessities, at inflated prices, from shops owned by their masters.

51 Taken from Cain and Hunt (eds) (1979) (original reference 'Engels, Ludwig Feuerbach and the End of Classical German Philosophy', MESW [3] III, 370-372 [from Marx and Engels Selected Works = Marx, K and Engels, F, [1969] Selected Works I and II, Progress, Moscow] 
the old feudal laws while giving them a bourgeois content; in fact, directly reading a bourgeois meaning into the feudal name. ${ }^{52}$

As the doubtful boundaries between contract and labour, private and public law unravel so seriously, one may sympathise with a sense that, for the wage labourer, subject to state force supporting capital interests, the very notion of the 'rule of law' becomes suspect. The meaning ascribed to the term 'rule of law' is itself contentious, and is more apparent as an assertion of state hegemony than as a test of legitimacy. As this excursion through the scholarship associated with the histories of labour and law has revealed, it is no doubt with a historical purview that we may best come to understand the defensible limits of the term, ${ }^{53}$ yet it is least likely to be asserted on behalf of the wronged worker, even by those sympathetic to their cause. Even the Marxist historian E.P. Thompson, surveying his understanding of the concept of the rule of law via events in British history, assured himself of a meaningful security in the idea, yet for parameters he asserts ${ }^{54}$

Did a few foresters get a rough handling from partisan laws? What is that beside the norms of the Third Reich? Did the villagers of Winkfield lose access to the peat within Sinley Rails? What is that beside the liquidation of the kulaks?

\footnotetext{
${ }^{52}$ Cain and Hunt (eds) (1979 ,p. 123) (from Marx, Capital I, 505): 'The wage-form thus extinguishes every trace of the division of the working-day into necessary labour and surplus-labour, into paid and unpaid labour. All labour appears as paid labour....This phenomenal form, which makes the actual relation invisible, and, indeed, shows the direct opposite of that relation, forms the basis of all the juridical notions of both labourer and capitalist, of all the mystifications of the capitalistic mode of production, of all its illusions as to liberty, of all the apologetic shifts of the vulgar economists'.

Cain and Hunt (eds) (1979, p.156) (from Engels, 'Origin of the Family, Private property and the State', MESW[3], III, 326-330): 'The state is, therefore, by no means a power forced on society from without; just as little is it "the reality of the ethical idea", "the image and reality of reason", as Hegel maintains... The people's army of the Athenian democracy was an aristocratic public power against the slaves, whom it kept in check; however, a gendarmerie also became necessary to keep the citizens in check, as we related above. This public power exists in every state; it consists not merely of armed men but also of material adjuncts, prisons and institutions of coercion of all kinds, of which gentile [clan] society knew nothing. It may be very insignificant, almost infinitesimal, in societies where class antagonisms are still undeveloped and in out-of-the-way places as was the case at certain times and in certain regions in the USA. It [the public power] grows stronger, however, in proportion as class antagonisms within the state become more acute, and as adjacent states become larger and more populous....Having public power and the right to levy taxes...

Cain and Hunt (eds) (1979, p.164) (from Engels, 'Letter to Van Patten', 18.4.1883, MESC 340-341 [selected correspondence]: 'Marx and I, ever since 1845, have held the view that one of the final results of the future proletarian revolution will be the gradual dissolution and ultimate disappearance of that political organisation called the state; an organisation the main object of which has ever been to secure, by armed force, the economical subjection of the working majority to the wealthy minority...
}

${ }^{53}$ See for example Harvey, (1961), Fallon (1997).

${ }^{54}$ See Cole (2001); ; this quotation (from E.P. Thompson, Whigs and Hunters: The Origins of the Black Act, (1975), London: Allen Lane) Cole, at p. 183. See also Fine (1994). 
Certainly, a 'few foresters' getting a 'rough handling' and a few villagers losing access to their local peat-cutting facilities $d o$ seem trivial grievances in comparison with the norms of the Third Reich and the kulaks. Such examples are surprising from this socialist historian of the English working class when one considers the much closer analogy presented by the perspective of the beleaguered industrial community illustrated by Lewis Jones. ${ }^{55}$ Perhaps a more global view of history is necessary. As Simmonds (1985, p.145) explains, Pashukanis theorises the entire trajectory, from feudalism to public law sanction:

'within feudalism, rights were thought of as naturally and inherently unequal'...Within the framework of bourgeois legal thought, rights are no longer thought of as in principle unequal. The actual inequality of concrete rights must be explained at the level of principle by reference to willed transactions entered into by the legal subject...In so far as the state acts as guarantor of private relationships of exchange, it can appear as a public authority pursuing the impersonal interest in the maintenance of order. But when it acts beyond its role as guarantor of the market, the state is launched in a realm of pure expediency. This area of state activity does not really admit of legal interpretation. Legal theories that seek to cover all the state's activities, therefore, must necessarily distort reality.

The dramatised account of police deployment provided by Jones, set alongside the juridical discussion presented in Glasbrook Bros, points up the absolutely fine line indicated here. Indeed, the example, fictional and real, leads one to acknowledge that the state role as 'guarantor of the market' is itself inevitably politically and legally contestable, quite apart from any action 'beyond' such a role. In short, the Marxist position is logically unavoidable. Simmonds (p.145-6) is led to ask, in a clear challenge to modern glossatorial accounts of public law:

[...]is there anything very "legal" about public law theory or public law reasoning? Or are the forms of reasoning involved here basically the purposive and expediency oriented forms of thought characteristic of the administrator or the bureaucrat?[..].if the conceptual structure of the legal order is a product of the exchange relations of the market $[\ldots]$ we could read Pashukanis as pointing to the fact that, when the bourgeois state extends its role beyond that of general guarantor of the market, and uses rules in a markedly instrumental manner, it moves beyond the sphere which provides its basis of

\footnotetext{
${ }^{55}$ Nor was Lewis Jones exaggerating the gravity of the position - depending on your point of view, some threat to the idea of the rule of law was present throughout the early period of the $20^{\text {th }}$ century, with contingency plans for industrial unrest to be met with a formalised domestic military presence discussed at length - see Jeffery (1981).
} 
legitimacy. In enforcing rules that give clarity and stability to the legal relations of the market, the state can appear as the impersonal embodiment of the rule of law. But when it employs the law to implement ad hoc goals and purposes, the state can no longer plausibly cover itself with the trappings of legal right and obligation It is revealed as lacking any claim to legitimacy.

No doubt this discussion touches upon a myriad of uses of public law and of the reach of public law vis a vis private law. But, seen in this light, the issue of who pays for the deployment of a police force - the local council, as handmaiden of the state, or private industry, in circumstances of economically and politically sensitive dispute - is at the very heart of the theorisation of public and private law, with a significance far beyond the purely technical question of consideration in the law of contract, instead touching the very question of the rule of law itself. And arguably, beyond the narrative space, it is only with Marxist and neo-Marxist critiques of law that such insights become clear. ${ }^{56}$

Payment near or at bare subsistence level deprives the worker, not only of just payment, but also of sufficient payment to bestow any real freedom of action or of identity. What is clear from the historical facts and the dramatisation provided by Cwmardy and We Live is that the use of coercive forces in situations of just dispute and labour - a dangerous labour - yielding significant profit for others, is effectively an extraction of labour on sufferance. It is salutary to find that the textual references to slavery are more than merely rhetorical, that there is an ancient and direct link between these modern workers, mining and the very notion of slavery. In classical Roman law, the physical labour of mining had a symbolic as well as practical savagery - as well as a direct definitional link to slavery itself: enslavement by Jus Civile included Servi poenae - those condemned to death, or to enforced labour in the mines ${ }^{57}$ or to a contest with wild beasts in the arena, were considered enslaved (Curzon, 1989, p. 61).. Garnsey (1970, p.134) notes the association in the collective ancient mind between underground work and shame-

The early history of forced labour as a criminal sanction in Rome is badly documented. Metallum and Opus were both recognised penalties under Tiberius and Gaius. Both emperors are said to have imposed them on men of rank, and this was clearly considered outrageous. Metallum and opus metalli were 'plebeian' penalties, in the view of Marcianus' contemporary Callistratus.

\footnotetext{
${ }^{56}$ Contrast for example, Dawn Oliver whose useful text (1999) like those texts on Labour law, places emphasis upon the relationship between the public-private divide and the individual employment contract.

${ }^{57}$ Italics added.
} 
With their deaths trivialised, expert testimony ridiculed and just dispute criminalised, such images of slavery seem pertinent to those more recent figures failed by society and by law. The historiography of the labour contract is a cultural and philosophical as well as political and legal question, its relation to the individual and to state forces complex and subtle. Though political theory - most notably in the writings of Marx and Engels - chronicles these failings, the 'dramatised' chronicle reasserts the urgency and the rationality of the desire for change.

\section{CONCLUSION - 'THERE CAN NEVER BE ONE LAW'}

In this essay, the initial stimulus provided by the fiction of Lewis Jones prompted examination of the component ideas constituting the very fact of labour, of the forces impinging upon that fact and the rhetorics surrounding it. At very least it would appear that law, history and philosophy have all proved somewhat inadequate to the task of providing a direct and wholly earnest response to the material relationship between coercive practices and the human commodity that is labour. In particular, the rationales of law, from discrete doctrinal gloss to the broad and contestable conceptual boundary between public and private domains, all contribute to concealing these truths as liminal - as a kind of 'secret' subtext to the visible world of law. Against this background, it becomes clear why the Marxist analysis of the conundrum provided a most compelling account of the 'truth' for the workers of the time. Yet by the 1930's even Marxist theory had been overtaken by historical events and, given this context, fiction provided an accessible vehicle for understanding and reviewing the vigour of the outstanding political challenge. Nevertheless, as the above analysis has indicated, the theoretical vision provided by Marx still remains a potent force in moving forward with a critique of the boundaries of law.

Some reading this discussion may have been perplexed by the avoidance of clearly prominent issues - of the law concerning the management of public order, of the law concerning the 'right to strike'. The discussion could have been characterised as one concerning the nexus between public order and civil liberties, of the boundary between state controls and individual - and collective - freedoms. ${ }^{58}$ Certainly, the issue of public order was pivotal to debates of

\footnotetext{
58 In recent times, the law of England and Wales has become more orientated towards this approach, with the discourse of 'human rights' catering to individual freedoms and responsibilities, aligned with (some may say, counterbalanced by) more restrictive 'public order' legislation. The issue of collective action in industrial dispute in particular has been affected by the subtleties of cultural, political and legal change - the perspective in labour law texts already described is partly accounted for by the emphasis upon individual employment rights,
} 
the time. The people of Tonypandy and of Wales, were utterly shocked by the ready deployment of police and of troops, and of the ready use of violence, in the name of the British Government - despite the fact that there was never any 'reading of the Riot Act'. 59 But to keep faith with the central jurisprudential enquiry thrown up by the events and by the text, the discussion has focussed upon the intimate relationship between the opportunity for effective engagement with the terms of the labour contract through industrial action and the use and financing of coercive forces - 'what they failed to understand was why, when the advantage was with them, the police should be placed at the disposal of the owners'.

As has been suggested, this question was answered, some years later, by judges in a seemingly less significant dispute; that adjudicated in Glasbrook Bros v Glamorgan County Council. Taking advantage of dramatic license, Lewis Jones choreographs elements of the Tonypandy debacle with other significant events - altering some aspects of chronological precision in order to render more potent the unfolding of educative political narrative. Writing from the vantage point of the 1930's, looking back over the preceding decades, his text pulses with the injustice of the apparent juristic support for capital with coercion. In a direct expression of their experience of a failure of law, the workers of Cwmardy believe that 'right' is determined by 'might', that there 'can never be one law that is good for the tiger and the lamb' and that this corrupted norm forms the foundation of the support of the State for capital and against citizens. The failure of their struggle to win meaningful influence through the democratic process alongside the partiality of State mechanisms, convince them of the failure of law. Singular in the creation of a historiographic, political fiction capable of educating a community to action, the work of Lewis Jones highlights some key issues for political and legal theory. No doubt for many legal commentators, the juxtaposition and 'politicisation' of the case of Glasbrook Bros - after all, a case distant from the Tonypandy dispute and simply adjudicating the parameters of payment in a particular case - is an

with a diminution in collective bargaining powers. With such protections for individuals, (ranged alongside redundancy, unemployment and welfare provisions) union membership and collective bargaining, it may be argued, no longer reflect the 'life and death' conflicts of yesteryear. Nevertheless, the miner's strike of the 1980's provides some powerful discussion points. With jobs and communities under threat, industrial action remained a key tool. When it came to the problems in the Nottingham coalfield the Metropolitan Police were called in to strengthen the local police presence, and their brutal tactics proved controversial. The failure to hold a full ballot of members robbed the miner's union (the NUM) of its legitimacy and this was exploited to the full by Conservative politics. It is now widely recognised that had a ballot been held, the vote would have been strong and the strike would have been formally supported. Thus, however attenuated, such rights need careful protection (see fn 87 for further brief comment). My thanks to Helen Milgate for comment on this matter.

${ }^{59}$ It is intriguing to consider to what extent this response from London was affected by prejudices of class; even more intriguing to consider the extent to which it was affected by race - for decades the Welsh as a people had been oppressed by draconian language laws and remained the butt of a kind of 'neighbour state racism' in many subtle ways. 
unnecessary excursion to place alongside this novel. Yet viewed through the eyes of this community, searching throughout to understand the roots of their impotence, the normalisation of the use of force by state actors in domestic industrial conflict is an issue central to the immanent impotence of the workforce, to an understanding of the relationship between public and private law and, ultimately, to the credibility of the rule of law itself.

From the failure of justice in the public inquest, to the public/private deployment of police, to the criminalisation of workers of integrity, Jones demonstrates the organic strictures of purportedly independent legal nomenclatures. His attempts to represent the interests of the workers thwarted, the main protagonist, Len, is sentenced to hard labour. His 'real' counterparts, Will John, Henry Hopla and John Hopla, were similarly arraigned and wronged by the law. John Hopla 'died a broken man' in his early twenties, shortly after his release. ${ }^{60}$ With this context, the perspective of Pashukanis (1989, p. 173) is not merely an analysis of some eccentric and dystopic capitalist legal system, but instead demonstrates the interdependence of these nomenclatures in the creation of capitalism, particularly in relation to the link between criminal law and labour law:

...In the Middle Ages, every person who tried to follow a trade without being a member of a guild was thought to be a law-breaker. The capitalist bourgeoisie, scarcely had it emerged, declared that the workers' attempts to join forces in associations were criminal...from the purely sociological standpoint, the bourgeoisie maintains its class rule and suppresses the exploited classes by means of its system of criminal law. In this respect, its courts and its private, 'voluntary' organisations of strike-breakers are pursuing one and the same end...

Though there was formal legislative support for trade unions and voluntary associations by the early $20^{\text {th }}$ century, the rapid path from collective action to criminalisation depicted by Jones provides corroboration that capital power still ruled - though the form of law vouchsafed democratic structures, practice could still diverge. And, as we have seen, more recent critical insights may become blunted in the explication of theory as well as by doctrine. $^{61}$ Global political change too may intervene - in the late 1930's, the 'pure'

\footnotetext{
${ }^{60}$ Smith, p. 135.

${ }^{61}$ Hugh Collins for example recognises the particular partiality discoverable in the history of the law of contract yet chooses the formalistic example of individual employment law in the case of Sagar v Ridehalgh to make his point, a surprising though perhaps strategic choice for a book entitled Marxism and Law: Collins (1982, p. 59) acknowledges that 'the tangled web of legal doctrines can conceal anachronistic survivals as well as permitting subtle metamorphoses of the existing legal doctrines'.
} 
ideological wars at home and in Spain became submerged by the overpowering and new threats posed by the Second World War. No doubt as a result of the fact that the larger political failures of communism were apparent by the time of writing the novel, in 1937, Lewis Jones indicates to his readers that communism as Marxism is not the way forward ${ }^{62}$ but the text is clear regarding the utter failure of democratic process and of law. Jones did not live to complete the narrative directive in relation to this, but the ghost-written finale remains obdurate on the significant failure of integrity in law: ${ }^{63}$

They are fighting to keep a principle which they and their fathers won through suffering many years ago...the company has been clever and used the poverty of our own people to turn some of them into scabs...they have kept our men down the pit through fear of starvation on top...yes...they made us sell our freedom for a job'.

During the strike, some of us wondered why the police should be sent in against us. But since then, we have learned the Government doesn't keep them just for chasing criminals. No. They keep them to maintain law and order and everything that we do that is in our own interest and against that of the company is illegal and disorderly. They use the police to smash us with their batons; then summons us for a riot which they themselves have made. And after this, before we know where we are, they use magistrates and judges to twist the law and turn us into criminals, then send us to jail. Jones's dramatisation demonstrates that fiction may assist in retrieving a more complete and representative account of cultural and legal failings than can be achieved by history and theory alone. It can certainly lead one to view cognate specialisms in law, as well as individual doctrine, with a fresh eye. This retrieval may extend to a more profound engagement with the public-private divide and to the very notion of the rule of law itself. Fictions may be needed, not merely as an educative tool, but also to counter the 'truth' of history and of law with the truths of historiography and critique. A truly conscientious legal theory should take account of the possibility of present, as well as historical instances of such elisions. Modern industrial disputes may continue to pose such difficulties ${ }^{64}$, but so too will

For a survey of the contribution of American scholarship to the notion of Labour Law and in particular to the notion of collective bargaining, see Conaghan, (1987).

${ }^{62}$ Marx is described (p. 320) in Cwmardy as not only 'heavy and dry' but also 'out of date'.

${ }^{63}$ We Live, pp. 817-818.

${ }^{64}$ As did the miner's strike of 1984-5, where Prime Minister Margaret Thatcher analysed the dispute in terms of external and internal 'war' with the 'rule of law':

"We had to fight the enemy without in the Falklands. We always have to be aware of the enemy within, which is much more difficult to fight and more dangerous to liberty...I must tell you that what we have got is an attempt to substitute the rule of the mob for the rule of law, and it must not succeed...' (from Campbell, 2003, p. 374). 
larger disputes of ideological note, where individuals and groups of political integrity are denied their own narrative, demonised and crystallised within the formal structures and logics of law. In South Wales in the early $20^{\text {th }}$ century, and in the dramatisation by Jones, the State's willingness to turn force against a significant body of citizenry had signalled a failure not simply in political process but also, we may come to believe, in law.

\section{REFERENCES}

Atiyah, P.S. (1995) An Introduction to the Law of Contract, Oxford: Clarendon Press

Banaji, Jairus (2003) 'The Fictions of Free Labour: Contract, Coercion, and So-Called Unfree Labour', Historical Materialism, vol 11:3, 69-95

Cain, M. And Hunt, A. (eds) (1979) Marx and Engels on Law, London, New York: Academic Press

Campbell, John (2003) Margaret Thatcher, the Iron Lady, London: Jonathan Cape

Cohen, G.A. (1997)'The Structure of Proletarian Unfreedom’ in Goodin, Robert and Pettit, Philip (eds) Contemporary Political Philosophy, Blackwell Philosophy Anthologies, Oxford and Malden Mass: Blackwell, 429-445

Cole, Daniel H. (2001)“ “An Unqualified Human Good”: E.P. Thompson and the Rule of Law', Journal of Law and Society, Volume 28 (2), 177-203

Collins, Hugh (1982) Marxism and Law, Oxford: Oxford University Press

Collins, Hugh (1993) The Law of Contract, London,: Butterworths

Conaghan, Joanne, (1987) 'Critical Labour Law: The American Contribution', Journal of Law and Society, (14) 3, 334-35

Curzon, L.B., (1981) Roman Law, London: M\&E Handbook

Davies, Paul and Freedland, Mark (eds) (1983)Kahn Freund's Labour and the Law, $3^{\text {rd }}$ edn, London: Stevens and Son

Deakin, Simon and Morris, Gillian (1998) Labour Law, $2^{\text {nd }}$ edn, London: Butterworth Edwards, Richard (2010, $1^{\text {st }}$ October)'Police offered right to strike' The Telegraph, http://www.telegraph.co.uk/news/uknews/law-and-order/8038086/Police-offered-right-tostrike.html

Fallon, Richard H. (1997) “The Rule of Law" as a Concept in Constitutional Discourse', Columbia Law Review, 97, 1; 1-56 
Fine, Robert (1994) 'The Rule of Law and Muggletonian Marxism: The Perplexities of Edward Thompson' Journal of Law and Society, 21 (2), 193-213

Fish, Stanley, (1989) Doing What Comes Naturally, Oxford: Clarendon Press

Garnsey, P. (1970) Social Status and Legal Privilege in the Roman Empire, Oxford: Oxford University Press

Gordley, James (1991)The Philosophical Origins of Modern Contract Doctrine, Oxford: Clarendon Pres

Harvey, W. Burnett (1961) 'The Rule of Law in Historical Perspective', Michigan Law Review, Vol. 59, No. 4, 487-500

Harvie, Christopher (1991) The Centre of Things - Political Fiction in Britain from Disraeli to the Present, London: Unwin Hyman Ltd

Holton, Robert J. (1981) 'Marxist Theories of Social change and the Transition from Feudalism to Capitalism', Theory and Society, Vol 10, No. 6, 833-867

Hutcheon, Linda (1988) A Poetics of Postmodernism: History, Theory, Fiction, London: Routledge

Jeffery, Keith, (1981)'The British Army and Internal Security 1919-1939’, The Historical Journal 24, 2, 377-397

Jones, Lewis, (2006) Cwmardy and We Live, Cardigan, Parthian Books, Library of Wales (first published 1937)

Keen M. (1990) English Society in the Later Middle Ages 1348-1500 London: Penguin Book Lewis, Roy (ed) (1986) Labour Law in Britain, Oxford: Blackwell

McLellan, David (ed) (2000) Karl Marx, Selected Writings, $2^{\text {nd }}$ edn., Oxford,:Oxford University Press

Oliver, Dawn (1999) Common Values and the Public-Private Divide, Cambridge: Cambridge University Press

Pashukanis, Evgeny (1989) Law and Marxism: A General Theory, London: Pluto Press

Pateman , Carole (1988) The Sexual Contract, Oxford: Polity Press

Simmonds, Nigel, (1985) 'Pashukanis and Liberal Jurisprudence', Journal of Law and Society, 12 (2), 135-151

Smith, Dai (1999) Wales: A Question for History, Bridgend: Seren

Thomas, Paul (1985) 'Mixed Feelings: Raymond Williams and George Orwell' Theory and Society, Vol. 14, No. 4, 419-44

Thompson, E.P. (1975) Whigs and Hunters: The Origins of the Black Act London: Allen Lane 
Trevelyan, G.M. (1986) A Shortened History of England, London: Penguin Books

Trotsky, Leon (2005) Literature and Revolution, (first published in 1924) ed. Wm Keach, Chicago: Haymarket Books

Williams, Raymond (1982) 'the language of the working-class novel of the 1930's' in The Socialist Novel in Britain, ed H. Gustav Klaus, London: Harvester, 133-4. 